\title{
THE RELATIONSHIP BETWEEN TEACHERS' EPISTEMOLOGICAL BELIEFS AND PUPIL CONTROL IDEOLOGY
}

\author{
ÖĞRETMENLERIN EPISTEMOLOJIK İNANÇLARI VE ÖĞRENCİ KONTROL \\ İDEOLOJILLERİ ARASINDAKİ İLİSTKI
}

Alper AYTAÇ ${ }^{1}$

\begin{abstract}
This study aims to analyze the relationship between teachers' epistemological beliefs and pupil control ideology. It was designed using a correlational survey model. The sample in this study consisted of 228 teachers. The epistemological beliefs scale and the pupil control ideology scale were used during the data collection process. The data was analyzed using both Pearson correlation analysis and multiple linear regression analysis. Study findings revealed that there is a moderate, positive relationship between the dimensions of epistemological beliefs termed the belief that learning is tied to talent (BLTT) and the belief that there is one right way to learn (BRWL) and pupil control ideology. Findings also indicated that the BLTT and BRWL dimensions significantly predict pupil control ideology. Based on these findings, epistemological beliefs were found to account for $28 \%$ of the total variance in relation to pupil control ideology. Some recommendations have been put forth in accordance with these findings.
\end{abstract}

Keywords: Epistemological beliefs, pupil control ideology, teachers.

\section{$\ddot{O} \mathbf{z}$}

$\mathrm{Bu}$ araştırmanın amacı öğretmenlerin epistemolojik inançları ve öğrenci kontrol ideolojileri arasındaki ilişkiyi incelemektir. Araştırma, ilişkisel tarama modeli ile tasarlanmıştır. Araştırmanın örneklemini 228 öğretmen oluşturmaktadır. Verilerin toplanmasında epistemolojik inanç ölçeği ve öğrenci kontrol ideolojileri ölçeği kullanılmıştır. Verilerin analizinde pearson korelasyon analizi ve çoklu doğrusal regresyon analizi kullanılmıştır. Araştırma sonuçlarına göre öğrenmenin yeteneğe bağlı olduğuna inanç (ÖYBİ) ve tek bir doğru olduğuna inanç (TBDİ) epistemolojik inanç boyutları ile öğrenci kontrol ideolojileri arasında pozitif yönde ve orta düzeyde anlamlı ilişkiler tespit edilmiştir. Ayrıca, ÖYBİ ve TBDİ epistemolojik inanç boyutlarının öğrenci kontrol ideolojilerini anlamlı şekilde yordadığı tespit edilmiştir. Buna göre epistemolojik inançlar, öğrenci kontrol ideolojilerine ait toplam varyansın \% 28'ini açıklamaktadır. Sonuçlar doğrultusunda birtakım önerilerde bulunulmuştur.

Anahtar Kelimeler: Epistemolojik inançlar, öğrenci kontrol ideolojileri, öğretmenler.

\footnotetext{
${ }^{1}$ Milli Eğitim Bakanlı̆̆ı, Cumhuriyet İlkokulu Sınıf Öğretmeni, İznik/Bursa, alperaytac10@gmail.com, Orcid: 0000-0002-5087-8482
}

Makale Türü: Araştırma Makalesi - Geliş Tarihi: 04.01.2021 - Kabul Tarihi: 08.04.2021

DOI:10.17755/esosder.853560

Atıf için: Elektronik Sosyal Bilimler Dergisi, 2021;20(79): 1205-1217

The population of this study consisted of 420 teachers working in a province of Turkey during the 2018-2019 academic year. 


\section{INTRODUCTION}

Epistemology is a fundamental branch of philosophy which investigates and questions the nature, source, and potentiality of knowledge (Yazıc1, 2016). Epistemological beliefs, on the other hand, signify an individual's subjective sense of self-acceptance regarding the nature and source of knowledge (Hofer, 2001). There have been several models developed to gauge and evaluate epistemological beliefs. These models can be sorted into two groups: onedimensional and multi-dimensional models. It is noteworthy that the models of epistemological beliefs that emerged in the early 1960s were one-dimensional (Bahçivan, 2017; Hofer and Pintrich, 1997). Schommer (1990), criticizing the fact that one-dimensional models of epistemological beliefs focus solely on knowledge, asserted that epistemological beliefs are also related to the acquisition of knowledge - in other words, related to the nature of learning as well as knowledge itself, and she developed a multi-dimensional model accordingly. According to her model, individuals who believe that learning is tied to process and effort possess developed epistemological beliefs, while individuals who believe that learning is tied to talent rather than effort and that there is only one way to learn have undeveloped epistemological beliefs (Schommer, 1993, 1994). Therefore, it is reasonable to assert that epistemological beliefs constitute an important part of the learning and teaching process (Demir and Akınoğlu, 2010; Pajares, 1992). Similarly, many studies in the body of relevant literature (Cano, 2005; Chan, 2003; Deryakulu, 2004; Tezci, Erdener, and At1c1, 2016) show that epistemological beliefs are tied to many factors in the learning-teaching process such as learning approaches, learning strategies, problem-solving skills, and teaching perceptions. Accordingly, teachers' epistemological perspectives may affect the strategies and understandings of teaching they embrace during the learning and teaching process. In addition, Aslan (2017) has stated that teachers' epistemological beliefs have an impact on their practices in the learning-teaching environment; thus, it can be said that teachers' epistemological beliefs affect the classroom atmosphere. Teachers' epistemological beliefs also affect their teaching approaches (Aslan, 2018), and in a similar vein, teaching approaches may be reflected in their approaches to classroom management (Aytaç and Uyangör, 2020a). Based on these ideas, teachers with developed epistemological beliefs embrace learnercentered perspectives, the selfsame teachers who embrace these perspectives create a positive classroom environment, and they therefore provide students with learning experiences where they are able to freely express themselves. Consequently, teachers' epistemological beliefs may affect their perceptions of a student's role in a classroom.

Pupil control ideology refers to a teachers' sense of self-acceptance regarding pupil control during the learning and teaching process (Y1lmaz, 2007). Pupil control ideology can be placed into two groups: custodial pupil control ideology and humanistic pupil control ideology. Teachers who are more prone to embrace custodial pupil control ideology are advocates of the idea that students always need to be kept under control. That custodial ideology, based on the principle that students require supervision, uphold the idea that students should be expected to unquestioningly follow rules and instructions set by their teachers, who are considered to be authority figures (Packard, 1989; Willower, Eidell, and Hoy, 1967). On the other hand, humanistic pupil control ideology does not emphasize matters such as a student's grasp of a subject or his or her ability to exhibit proper behavior; these matters are seen as irrelevant. Students are asked to take an active role in becoming selfactualized, in learning how to self-regulate, and in personally engaging with the learning process. In other words, humanistic ideology revolves around creating environments where students can learn and improve themselves on their own through learning experiences and where the teacher is not the center of the classroom (Hoy, 2001; Lunenberg, 1983). Thus, it can be said that pupil control ideology is important factor in the learning and teaching 
process. Relevant studies in the literature (Atik, 2020; Baş and Beyhan, 2013; Gilbert, 2012; Işık-Gürşimşek, 2014; Karataş-Erduran, 2012; Kiriş-Avaroğulları and Karpınar, 2020; ParkerHart, 2019; Utar, 2013; Yaman, 2012) show that pupil control ideology is related to a variety of factors encountered in the learning and teaching process such as understandings of teaching and learning, self-efficacy for teaching, academic optimism, grading techniques, motivation, classroom management approaches, attitude towards the teaching profession, and school climate.

A number of studies that investigate the relationship between epistemological beliefs and a myriad of variables were found after a careful review of the body of relevant literature (Aytaç and Uyangör, 2020b; Bıkmaz, 2017; Biçer, Er, and Özel, 2013; Cano, 2005; Chan, 2003; Cheng, Chan, Tang, and Cheng, 2009; Deryakulu, 2004; Hofer, 2004; Phan, 2008; Rodrigez and Cano, 2006; Schommer-Aikins and Hutter, 2002; Turan, 2018; Vecaldo, 2020). Similarly, there are a considerable number of studies that examine the relationship between pupil control ideology and assorted variables (Atik, 2020; Beatty, 2002; Çobanoğlu, Kaya and Angay, 2015; Halpin, Goldenberg and Halpin, 1977; Helsel, 1971; Hoy and Jalovick, 1979; Iş1k-Gürşimşek, 2014; Jones and Blankenship, 1972; Karataş-Erduran, 2012; Kılınç, 2014; Leppert and Hoy, 1972; Lunenberg, 1991; Rideout and Morton, 2007; Rideout and Windle, 2010; Schmidt, 1992; Utar, 2013; Yaman, 2012; Y1lmaz, 2007, 2009, 2011). Although there are a variety of studies that focus on the relationship between different variables and both epistemological beliefs and pupil control ideology, considered essential in the learning and teaching process, a study investigating the relationship between epistemological beliefs and pupil control ideology themselves was not encountered. In addition, according to the study of Baş and Beyhan (2013), understandings of teaching affect pupil control ideology. According to the results of this study, teachers who have a traditional understanding of teaching tend to control students' behaviors in the classroom environment. There are many studies showing that epistemological beliefs also affect teaching-learning conceptions (Chan and Elliott, 2004; Tezci et al., 2016; Wong, Chan and Lai, 2009). According to the results of these studies, individuals who have undeveloped epistemological beliefs have rather traditional understandings of teaching, whereas individuals with developed epistemological beliefs have contemporary understandings of teaching. In other words, it can be said that teachers with undeveloped epistemological beliefs tend to control students' behaviors in the classroom since they apply traditional teaching approaches in the learning-teaching process. As a result, when the research results are examined holistically, it is understood that the epistemological beliefs of the individuals affect their understanding of teaching, while their understandings of teaching affect their pupil control ideology. Considering this chain of relationships, it can be said that teachers' epistemological beliefs may be related to pupil control ideology. Therefore, it is believed that this study will make a novel contribution to the current body of literature. Also, results of this study may provide institutions that are in charge of in-service teachers' training with fresh and diverse perspectives. To that end, the purpose of this study is to examine the relationship between teachers' epistemological beliefs and pupil control ideology. Within the purview of this study, answers to the following questions were sought:

1. Is there a statistically significant relationship between teachers' epistemological beliefs and pupil control ideology?

2. Do teachers' epistemological beliefs significantly predict pupil control ideology?

\section{METHOD}

\subsection{Model}

Correlational survey models determine the presence or absence of a reciprocal relationship between variables (Karasar, 2006). As this study investigated the relationship 
between teachers' epistemological beliefs and pupil control ideology, a correlational survey model was selected to analyze the relationship. In addition, within the scope of the second study question of this research, it was aimed to examine the predictive effect of epistemological beliefs on pupil control ideology. Therefore, the predictive relational design was preferred among the correlational research designs.

\subsection{Population and Sample}

The population of this study consisted of 420 teachers working in a province of Turkey during the 2018-2019 academic year. Convenient sampling method was preferred in sample selection. In this context, scales were applied by the researcher within the scope of the study. Some of the participants did not complete the scales because they did not want to participate in the study, and some of them did not receive feedback. This is why the entire population has not been reached. In this direction, the sample of the study consisted of 228 teachers. Accordingly, the sample constitutes approximately 54\% of the population. According to Özen and Gül (2007), in correlational studies, the sample should constitute at least $30 \%$ of the population. In this respect, it can be said that the sample represents the population. Data from the sample can be found in table 1 .

Table 1. Demographic Profile of the Sample

\begin{tabular}{|c|c|c|c|}
\hline Variables & Groups & (f) & $(\%)$ \\
\hline \multirow{2}{*}{ Gender } & Female & 142 & 62.3 \\
\hline & Male & 86 & 37.7 \\
\hline \multirow{2}{*}{$\begin{array}{c}\text { Teacher Subject } \\
\text { Areas }\end{array}$} & Primary Education & 82 & 36.0 \\
\hline & Subject Teacher & 146 & 64.0 \\
\hline \multirow{4}{*}{$\begin{array}{c}\text { Years of } \\
\text { Experience }\end{array}$} & $1-5$ & 73 & 32.0 \\
\hline & $6-10$ & 63 & 27.6 \\
\hline & $11-15$ & 49 & 21.5 \\
\hline & $16+$ & 43 & 18.9 \\
\hline
\end{tabular}

As indicated in table $1,142(62.3 \%)$ of the teachers who participated in the study were female and $86(37.7 \%)$ were male. $82(36.0 \%)$ of the teachers were primary education teachers, and $146(64.0 \%)$ of them were subject teachers. $73(32.0 \%)$ of teachers who participated in the study had between 1 and 5 years of work experience, $63(27.6 \%)$ had between 6 and 10 years, $49(21.5 \%)$ had between 11 and 15 years, and 43 (18.9\%) had 16 years or more.

\subsection{Data Collection Tools}

2.3.1. Epistemological beliefs scale (EBS): The epistemological beliefs scale (EBS) developed by Schommer (1990) was adapted by Deryakulu and Büyüköztürk (2002) for use in a Turkish cultural context. After conducting exploratory factor analysis, a scale consisting of three dimensions and 35 items was devised. Subsequently, the factor structure was reexamined by Deryakulu and Büyüköztürk (2005); they determined that the factor structure of the scale remained unchanged. Also, one of the items was taken out of the scale, and the final version of the scale contained 34 items. The Belief that Learning is Tied to Effort (BLTE) scale has 17 items, while the Belief that Learning is Tied to Talent (BLTT) subdimension consists of 8 items and the Belief that there is one Right Way to Learn (BRWL) sub-dimension includes 9 items. The Cronbach's alpha values for these dimensions were found to be $.84, .69, .81$, respectively (Deryakulu and Büyüköztürk, 2005). In addition, according to the results of the reliability analysis conducted within the scope of this study, Cronbach's alpha values; It was determined as .65 for BLTE sub-dimension, .73 for BLTT sub-dimension, and .72 for BRWL sub-dimension. In the original scale, the 17-item first 
dimension included negatively-phrased items, while other two dimensions had positivelyphrased items. However, the technique of line-by-line coding was used while coding the first dimension in order to facilitate the interpretation process. In this context, the items in this subdimension were not reverse-coded. A high score on each dimension of this scale indicates that participant beliefs regarding the dimensions in question are also strong (Eren, 2006).

2.3.2. Pupil control ideology scale (PCI): The pupil control ideology scale (PCI) developed by Willower et al. (1967) was adapted by Y1lmaz (2002) for use in a Turkish cultural context. The Cronbach's alpha value of the scale, which has only one dimension and 10 items, was calculated to be .72. In addition, according to the results of the reliability analysis conducted within the scope of this study, the Cronbach's alpha value was determined as .76. In addition, this single dimension accounts for $30 \%$ of the total variance. A high score on the scale indicates that the participant possesses a custodial pupil control ideology, while a low score indicates that the participant possesses a humanistic pupil control ideology (Y1lmaz, 2007).

\subsection{Data Analysis}

The scales were applied only to teachers who volunteered to participate in the study. During the data entry process, 12 sheets of data were removed from the data set as they were improperly filled out. The data set was then checked for extreme values, and two data were subsequently removed from it. Finally, measures of kurtosis and skewness for the data were calculated. The data in this scope are presented in the table 2.

Table 2. Measures of Kurtosis and Skewness

\begin{tabular}{lccc}
\hline Dimensions and Scales & $\mathrm{N}$ & Kurtosis & Skewness \\
\hline BLTE & 228 & -.68 & -.23 \\
BLTT & 228 & -.15 & .57 \\
BRWL & 228 & -.35 & .24 \\
EBS & 228 & .24 & .17 \\
PCI & 228 & -.17 & .00 \\
\hline
\end{tabular}

The data in table 2 indicate that kurtosis and skewness in the data set for the combined dimensions of each individual scale range from -1 to +1 . Şencan (2005) states that measures of kurtosis and skewness in a data set ranging from -1 to +1 are sufficient to infer that data is normally distributed. Therefore, the data was deemed to possess a normal distribution. The Mahalanobis distance measures were examined in order to test the data set for multivariate normal distribution, and no extreme values that would upset the normal distribution were found. A correlation analysis was first conducted in order to examine the issue of multicollinearity among predictor variables, and high correlations (over 0.70 ) were not found. Following this, tolerance levels and the variance inflation factor (VIF) were also evaluated with regard to the issue of multicollinearity. Field (2005) noted that the VIF values lower than 10 and tolerance levels higher than 0.2 are sufficient to safely rule out any issues with multicollinearity. Accordingly, the tolerance level and the VIF value calculated during regression analysis showed that the data set doesn't have a problem regarding multicollinearity, and multiple regression analysis was therefore used to examine this study's data set. 


\section{FINDINGS}

Findings from the study were evaluated in this section. Findings relating to the two questions will be given in sequential order. Within this framework, the results from Pearson correlation analysis regarding the relationship between epistemological beliefs and pupil control ideology were included in table 3.

Table 3. Pearson correlation analysis results

\begin{tabular}{lc}
\hline & PCI \\
\hline BLTE & $-.091 *$ \\
BLTT & $.448 * *$ \\
BRWL & $.441 * *$ \\
\hline$* \mathrm{p}>.05, * * \mathrm{p}<.01$ & \\
\hline
\end{tabular}

Table 3 displays the results of the Pearson correlation analysis between variables. As indicated in the results, there is no statistically significant relationship between the BLTE dimension and pupil control ideology $(\mathrm{r}=-.091, \mathrm{p}>.05)$. Results also show that there is a moderate, positive relationship between the BLTT $(r=.448, p<.01)$ and BRWL $(r=.441, p<.01)$ dimensions and pupil control ideology.

In accordance with the scope of the second question, table 4 shows the results of multiple linear regression analysis regarding the extent to which epistemological beliefs predict pupil control ideology.

Table 4. Multiple linear regression analysis results

\begin{tabular}{lccccccc}
\hline & $\mathrm{B}$ & $\begin{array}{c}\text { Standard } \\
\text { Error }\end{array}$ & $\beta$ & $\mathrm{t}$ & $\mathrm{p}$ & $\begin{array}{c}\text { Zero } \\
\text { order (r) }\end{array}$ & Partial (r) \\
\hline Constant & 1.455 & .505 & & 2.882 & .004 & & \\
BLTE & -.055 & .107 & -.030 & -.516 & .606 & -.091 & -.034 \\
BLTT & .357 & .075 & .310 & 4.788 & .000 & .448 & .305 \\
BRWL & .288 & .059 & .309 & 4.892 & .000 & .441 & .311 \\
\hline $\mathrm{R}=0.527$ & $\mathrm{R}^{2}=.278$ & & & & & & \\
$\mathrm{~F}_{(3-224)}=28.759$ & $\mathrm{p}=.000$ & & & & & & \\
\hline
\end{tabular}

Table 4 provides detailed information regarding the extent to which epistemological beliefs predict pupil control ideology. Analyses showed that there is a moderate, significant relationship between epistemological beliefs and pupil control ideology $\left(\mathrm{R}=.527, \mathrm{R}^{2}=.278\right.$, $\left.\mathrm{F}_{(3-224)}=28.759, \mathrm{p}<.01\right)$. The BLTT $(\beta=.310, \mathrm{p}<.01)$ and BRWL $(\beta=.309, \mathrm{p}<.01)$ dimensions were found to be statistically significant predictors of pupil control ideology, while the BLTE $(\beta=-.030 ; \mathrm{p}>.05)$ dimension was not found to be a significant predictor of pupil control ideology. Epistemological beliefs accounted for $28 \%$ of the total variance in relation to pupil control ideology. Table 4 also includes details regarding partial correlations between epistemological beliefs and pupil control ideology. These partial correlations revealed that there is a moderate, positive relationship between the BLTT $(r=.305, p<.01)$ dimension and pupil control ideology; the other two dimensions were also assessed in kind. Bearing this in mind, there is also a moderate, positive relationship found between the BRWL dimension and pupil control ideology $(r=.311, \mathrm{p}<.01)$. 


\section{DISCUSSIONS, CONCLUSIONS AND RECOMMENDATIONS}

This study aimed to investigate and elucidate the relationship between teachers' epistemological beliefs and pupil control ideology. In this section, the discussion and conclusions relating to the two research questions will be given in sequential order. Therefore, conclusions regarding reciprocal relationships between teachers' epistemological beliefs and pupil control ideology, the subject of the first question, were introduced first. Based on these conclusions, there is a moderate relationship found between the BLTT and BRWL dimensions and pupil control ideology, whereas no significant relationship was found between the BLTE dimension and pupil control ideology. Thus, as long as teachers possess epistemological perspectives in line with the ideas that learning is tied to talent and that knowledge is invariable, they will be more likely to adopt custodial pupil control ideology.

Regression analysis was used in an effort to determine the predictive effect of epistemological beliefs on pupil control ideology in keeping with the scope of the second question. Results from the analysis showed that the BLTT and BRWL dimensions were found to be statistically significant predictors of pupil control ideology, whereas the BLTE dimension didn't significantly predict pupil control ideology. These results indicate that the important factor behind teachers' belief that students should be kept under supervision throughout the educational process is their beliefs that knowledge is invariable and that learning is tied to innate abilities and skills. In other words, it can be stated that teachers' epistemological beliefs affect their perceptions of students' position and progress during the educational process. Hence, teachers who have undeveloped epistemological beliefs are advocates of the idea that students need to be kept under control/supervision. According to the study of Iş1k-Gürşimşek (2014), there is a moderate relationship between custodial pupil control ideology and traditional educational beliefs. According to the study results, traditional educational beliefs are a significant predictor of custodial pupil control ideology. It can be said that a teacher who has a custodial belief in the control of the student in the classroom environment creates a traditional learning-teaching atmosphere (Lunenburg \& Cadavid, 1992; Willower et al, 1967). Similarly, according to the study of Baş and Beyhan (2013), there is a moderate relationship between pupil control ideology and traditional understandings of teaching. In addition, according to the study results, pupil control ideology is based on traditional understandings of teaching. According to Schommer (1990, 1993), individuals with undeveloped epistemological beliefs believe that knowledge is immutable and that learning is based on innate abilities, whereas teachers with developed epistemological beliefs believe that knowledge is relative and learning depends on effort. According to the study results of Tezci et al. (2016), it was determined that individuals with undeveloped epistemological beliefs have traditional understanding of teaching. Similar results have been obtained in many studies (Aytaç and Uyangör, 2020b; Chan and Elliott, 2004; Ekinci, 2017; Mahasneh, 2018; Turan, 2018). According to the study results of Aytaç and Uyangör (2020a), it was determined that individuals with traditional understandings of teaching have authoritarian-oppressive classroom management profiles. Similarly, the study results of Baş and Beyhan (2013) show that traditional understandings of teaching predict pupil control ideology. In other words, when the results of this study are taken as a whole, it shows that the individuals' understanding of teaching is based on their epistemological beliefs and that their understandings of teaching are the source of pupil control ideology. Also, given the fact that individuals' epistemological beliefs play a key role in affecting their understandings regarding teaching-learning (Hofer and Pintrich, 1997), the effect of epistemological beliefs on pupil control ideology becomes much easier to comprehend. In this context, it is possible to say that the relationship between epistemological beliefs and pupil control ideology is also supported by studies in the relevant literature. 
This study determined that teachers' epistemological beliefs and perspectives affect their perceptions of pupil control during the learning and teaching process. It has been determined that teachers who have undeveloped epistemological beliefs tend to control students in the learning-teaching process. This situation causes the traditional understanding of teaching to gain weight in teachers. However, the teacher profile of the curriculum that have been implemented since the 2005-2006 academic year in Turkey is completely different. Accordingly, the teacher should be in the position of directing the student, not controlling it in the classroom. This can be achieved by the teacher having a developed epistemological perspective. To this end, in-service training programs could be organized by the Ministry of Education in order to develop teachers' epistemological beliefs. Feucht, Brownlee and Schraw (2017) noted that individuals' epistemological beliefs could be improved with a variety of specialized training programs. Demir and Akınoğlu (2010) stated that individuals' epistemological beliefs can be improved through formal or informal education activities. Naturally, teachers' perspectives may influence their students' perspectives as well (Brownlee, 2004).

\section{REFERENCES}

Aslan, C. (2017) Examining epistemological beliefs of teacher candidates according to various variables. Eurasian Journal of Educational Research, 67, 37-50. https://doi.org/10.14689/ejer.2017.67.3

Aslan, S. (2018). İnvestigating the relation between educational philosophies adopted by prospective teachers and their teaching-learning conceptions. Pegem Journal of Education and Instruction, 8(2), 307-326. https://doi.org/10.14527/pegegog.2018.013

Atik, S. (2020). Analysis of the relationships between intrinsic motivation, self-efficacy for teaching, attitude towards the teaching profession and pupil control ideologies. International Journal of Eurasian Education and Culture, 10, 1315-1346. http://dx.doi.org/10.35826/ijoecc.238

Aytaç, A., \& Uyangör, N. (2020a). Öğretmenlerin öğretme-öğrenme anlayışları ile sınıf yönetimi stilleri arasındaki ilişki [The relationship between teachers' teaching-learning conceptions and their classroom management styles]. Akdeniz Ĕgitim Araştırmaları Dergisi, 14(31), 159-173. https://doi.org/10.29329/mjer.2020.234.8

Aytaç, A., \& Uyangör, N. (2020b). A relational study of pre-service teachers' epistemological beliefs, educational philosophy tendencies and teaching-learning conceptions. Educational Policy Analysis and Strategic Research, 15(4), 49-68. https://doi.org/10.29329/epasr.2020.323.3

Bahçivan, E. (2017). Eğitim bilimlerinde epistemoloji araştırmaları: Düne, bugüne ve gelecek perspektiflere eleştirel bakış [Epistemological research in educational sciences: Critical investigation of past, present and future perspectives]. Mersin Üniversitesi Eğitim Fakültesi Dergisi, 13(2), 760-772. https://doi.org/10.17860/mersinefd.301121

Baş, G., \& Beyhan, Ö. (2013). Öğretmen adaylarının öğretme-öğrenme anlayışları ile öğrenci kontrol ideolojileri arasındaki ilişki [Correlation between pre-service teachers' teaching-learning conceptions and their student control ideologies]. Hacettepe Üniversitesi Ĕ̈itim Fakültesi Dergisi, Özel Sayı(1), 14-26.

Beatty, T. H. (2002). The relationship between teacher sense of efficacy and pupil control ideology in urban middle schools. (Unpublished doctoral dissertation). The College of William and Mary in Virginia. https://dx.doi.org/doi:10.25774/w4-gz14-g513 
Bıkmaz, F. (2017). Öğretmen adaylarının öğretme-öğrenme anlayışları ve bilimsel epistemolojik inançlarının araştırılması: Boylamsal bir çalışma [Investigating the teaching and learning conceptions and scientific epistemological beliefs of pre-service teachers': A longitudinal study]. Eğitim ve Bilim, 42, 183-196. http://dx.doi.org/10.15390/EB.2017.4601

Biçer, B., Er, H., \& Özel A. (2013). Öğretmen adaylarının epistemolojik inançları ve benimsedikleri eğitim felsefeleri arasındaki ilişki [The relationship between the epistemological beliefs and educational philosophies of the teacher candidates adopted]. Eğitimde Kuram ve Uygulama, 9(3), 229-242.

Brownlee, J. (2004). An investigation of teacher education students' epistemological beliefs: Developing a relational model of teaching. Research in Education, 72, 1-17. https://doi.org/10.7227/RIE.72.1

Cano, F. (2005). Epistemological beliefs and approaches to learning: Their change through secondary school and their influence on academic performance. British Journal of Educational Psychology, 75(2), 203-221. https://doi.org/10.1348/000709904X22683

Chan, K-W. (2003). Hong Kong teacher education students' epistemological beliefs and approaches to learning. Research in Education, 69, 36-50. https://doi.org/10.7227/RIE.69.4

Chan, K., \& Elliott, R.G. (2004). Relational analysis of personal epistemology and conceptions about teaching and learning. Teaching and Teacher Education, 20, 817831. https://doi.org/10.1016/j.tate.2004.09.002

Cheng, M.H., Chan K-W., Tang, Y.F., \& Cheng, Y.N. (2009). Pre-service teacher education students' epistemological beliefs and their conceptions of teaching. Teaching and Teacher Education, 25, 319-327. https://doi.org/10.1016/j.tate.2008.09.018

Çobanoğlu, M., Kaya, O., \& Angay, A. (2015). The effects of pupil control ideology of teachers on their conflict management strategies. International Journal of Educational Methodology, 1(1), 35-41. https://doi.org/10.12973/ijem.1.1.35

Demir, S., \& Akınoğlu, O. (2010). Epistemolojik inanışlar ve öğretme öğrenme süreçleri

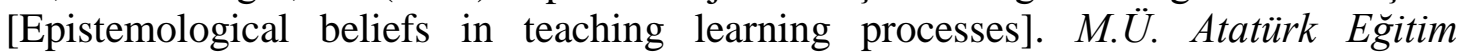
Fakültesi Ĕ̈itim Bilimleri Dergisi, 32, 75-93.

Deryakulu, D. (2004). Üniversite öğrencilerinin öğrenme ve ders çalışma stratejileri ile epistemolojik inançları arasındaki ilişki [The relationships between university students' learning and study strategies and their epistemological beliefs]. Kuram ve Uygulamada Ĕ̈itim Yönetimi, 3(10), 230-249.

Deryakulu, D., \& Büyüköztürk, Ş. (2002). Epistemolojik inanç ölçeğinin geçerlik ve güvenirlik çalışması [Validity and reliability study of epistemological beliefs questionnaire]. Eğitim Araştırmaları, 8, 111-125.

Deryakulu, D., \& Büyüköztürk, Ş. (2005). Epistemolojik inanç ölçeğinin faktör yapısının yeniden incelenmesi: Cinsiyet ve ögrrenim görülen program türüne göre epistemolojik inançların karşılaştırılması [The re-examination of the epistemological beliefs questionnaire's factor structure: Comparing epistemological beliefs in terms of gender and program type]. Eğitim Araştırmaları Dergisi, 18, 57-70.

Ekinci, N. (2017). Examining the relationships between epistemological beliefs and teaching and learning conceptions of lower-secondary education teachers. Inönü University 
Journal of the Faculty of Education, 18(1), 344-358. https://doi.org/10.17679/inuefd.307065

Eren, A. (2006). Üniversite ögrencilerinin genel ve alan-odaklı epistemolojik inanışlarının incelenmesi [Examining the general and domain-specific epistemological beliefs of undergraduates]. (Yayınlanmamış doktora tezi). Abant İzzet Baysal Üniverisitesi, Sosyal Bilimler Enstitüsü, Bolu.

Feucht, F. C., Brownlee, J. L., \& Schraw, G. (2017) Moving beyond reflection: Reflexivity and epistemic cognition in teaching and teacher education. Educational Psychologist, 52(4), 234-241. https://doi.org/10.1080/00461520.2017.1350180

Field, A. (2005). Discovering statistics using SPSS. London: Sage Publication.

Gilbert, M. J. (2012). The relationship between pupil control ideology and academic optimism. (Unpublished doctoral dissertation). Seton Hall University, New Jersey.

Halpin, G., Goldenberg, R., \& Halpin, G. (1973). Are creative teachers more humanistic in their pupil control ideologies? The Journal of Creative Behavior 7(4), 282-286. https://doi.org/10.1002/j.2162-6057.1973.tb01099.x

Helsel A. R. (1971). Value orientation and pupil control ideology of public school educators. Educational Administration Quarterly, 7(1), 24-33. https://doi.org/10.1177/0013161X7100700103

Hofer, B. K. (2001). Personal epistemology research: Implications for learning and teaching. Journal of Educational Psychology Review, 13(4), 353-383. https://doi.org/10.1023/A:1011965830686

Hofer, B. K. (2004). Epistemological understanding as a metacognitive process: Thinking aloud during online searching. Educational Psychologist, 39(1), 43-55. https://doi.org/10.1207/s15326985ep3901_5

Hofer, B. K., \& Pintrich, P. R. (1997). The development of epistemological theories: beliefs about knowledge and knowing and their relation to learning. Review of Educational Research, 67(1), 88-140. https://doi.org/10.3102/00346543067001088

Hoy, W. K. (2001) Pupil control studies: a historical, theoretical, and empirical analysis. Journal of Educational Administration, 39(5), 424-441. https://doi.org/10.1108/EUM0000000005812

Hoy, W. K., \& Jalovick, J. M. (1979). Open education and pupil control ideologies of teachers, The Journal of Educational Research, 73(1), 45-49. http://dx.doi.org/10.1080/00220671.1979.10885203

Işık-Gürşimşek, A. (2014). Preschool teacher candidates' pupil control ideology and educational beliefs. Education and Science, 39(171), 463-447.

Jones, L. P. \& Blankenship, J. W. (1972). The relationship of pupil control ideology and innovative classroom practices. Journal of Research in Science Teaching, 9(3), 281285.

Karasar, N. (2006). Bilimsel araştırma yöntemi [Scientific research method]. Ankara: Nobel Yayın Dağıtım.

Karataş-Erduran, F. (2012). Fen ve teknoloji öğretmenlerinin not vermek eğilimleri ile gözetimci ögrenci control ideolojileri arasındaki ilişki [The relationship between teacher' sgrading tendecy and pupil control ideologies as percived by teachers 
working in Turkish public school]. (Yayımlanmamış yüksek lisans tezi). Eskişehir Osmangazi Üniversitesi, Eğitim Bilimleri Enstitüsü, Eskişehir.

Kılınç, A. Ç. (2014) School teachers' pupil control ideologies as a predictor of teacher professionalism, The Anthropologist, $18(2), \quad$ 565-574, https://doi.org/10.1080/09720073.2014.11891574

Kiriş-Avaroğulları, A., \& Karpınar, O. (2020). The effect of preservice social studies teachers' pupil control ideologies on their classroom management beliefs. Elementary Education Online, 19(4), 2270-2281. https://doi.org/10.17051/ilkonline.2020.764057

Leppert, E., \& Hoy, W., K. (1972). Teacher personality and pupil control ideology. The Journal of Experimental Education, 40(3), 57-59.

Lunenberg, F. C. (1983). Pupil control ideology and self concept as a learner. Educational Research Quarterly, 8, 33-9.

Lunenberg, F. C. (1991). Educators' pupil control ideology as a predictor of educators' reactions to student disruptive behavior. The High School Journal, 74, 81-87.

Lunenburg, F. C., \& Cadavid, V. (1992). Locus of control, pupil control ideology, and dimensions of teacher burnout. Journal of Instructional Psychology, 19(1), 13-22.

Mahasneh, M., A. (2018). Investigation of the relationship between teaching and learning conceptions and epistemological beliefs among student teachers from Hashemite University in Jordan. European Journal of Contemporary Education, 7(3), 531-540. https://doi.org/ 10.13187/ejced.2018.3.531

Özen, Y, \& Gül, A. (2007). Sosyal ve eğitim bilimleri araştırmalarında evren-örneklem sorunu [Population-sampling issue on social and educational research studies]. Kazım Karabekir Ĕgitim Fakültesi Dergisi, 15, 394-422.

Packard, J. S. (1989), The pupil control studies, handbook of research on educational administration. (pp. 185-207). Boyan, N., NY: Longman.

Pajares, M. F. (1992). Teachers' beliefs and educational research: Cleaning up a messay construct. Review of Educational Research, 62(3), 307-332.

Parker-Hart, K. (2019). A correlational study on the relationship between pupil control ideology, color-blind racial attitudes and teacher efficacy among urban teachers (Unpublished doctoral dissertation). Liberty University, Virginia.

Phan, H. P. (2008). Exploring epistemological beliefs and learning approaches in context: A sociocultural perspective. Electronic Journal of Research in Educational Psychology, 6(3), 793-822. http://dx.doi.org/10.25115/ejrep.v6i16.1305

Rideout, G.W. \& Morton, L.L. (2007), Pre- service teachers' beliefs and other predictors of pupil control ideologies. Journal of Educational Administration, 45(5), 587-604. https://doi.org/10.1108/09578230710778213

Rideout, G., \& Windle, S. (2010). Beginning teachers' pupil control ideologies: An empirical examination of the impact of beliefs about education, mentorship, induction, and principal leadership style. Canadian Journal of Educational Administration and Policy, 104(1), 1-30.

Rodrigez, L., \& Cano, F. (2006). The epistemological beliefs, learning approaches and study orchestrations of university students. Studies in Higher Education, 31(5), 617-636. https://doi.org/10.1080/03075070600923442 
Schmidt, L. J. (1992). Relationship between pupil control ideology and the quality of school life. Journal of Invitational Theory and Practice, 45, 889-896.

Schommer, M. (1990). Effects of beliefs about the nature of knowledge on comprehension. Journal of Educational Psychology, 82(3), 498-504.

Schommer, M. (1993). Epistemological development and academic Performance among secondary students. Journal of Educational Psychology, 85(3), 406-411.

Schommer, M. (1994). Synthesizing epistemological belief research: Tentative understandings and provocative confusions. Educational Psychology Review, 6(4), 293-319.

Schommer-Aikins, M., \& Hutter, R. (2002). Epistemological beliefs and thinking about everyday controversial issues. Journal of Psychology, 136(1), 5-20.

Şencan, H. (2005). Sosyal ve davranışsal ölçümlerde güvenirlik ve geçerlik [Reliability and validity in social and behavioral measures]. Ankara: Seçkin Yayınc1lık.

Tezci, E., Erdener, M.A., \& Atıc1, S. (2016). The Effect of pre-service teachers' epistemological beliefs on teaching approaches. Universal Journal of Educational Research, 4(12A), 205-215.

Turan, M. B. (2018). The Relationship between university students' epistemological beliefs and teaching/learning conceptions. International Journal of Progressive Education, 14(3), 1-11. https://eric.ed.gov/?id=EJ1186529

Utar, N. (2013). Sinıf ögretmenlerinin öğrenci kontrol ideolojileri ile sinıf yönetimi yaklaşımları arasındaki ilişki [The relationship between pupil control ideology and classroom management approaches of primary school teachers] (Yayımlanmamış yüksek lisans tezi). Zirve Üniversitesi Sosyal Bilimler Enstitüsü, Gaziantep.

Vecaldo, R. T. (2020). Dimensionality and predictive validity of schommer epistemological questionnaire among Philippine pre-service teachers. International Journal of Instruction, 13(2), 767-782. https://doi.org/10.29333/iji.2020.13252a

Willower, D. J., Eidell, T. L., \& Hoy, W. K. (1967). The school and pupil control ideology. University Park: Pennsylvania State University Press.

Wong, A.K., Chan K., \& Lai, P. (2009). Revisiting the relationship epistemological beliefs and conceptions about teaching and learning of pre-service teachers in Hong Kong. The Asia-Pacific Education Researchers, 18(1), 1-19.

Yazıc1, S. (2016). Felsefeye giriş [İntroduction to philosophy]. İstanbul: Yeni İnsan Yayınevi.

Yaman, F. (2012). İlköğretim okullarında müdürlerin yönetsel etkililiği ve okul iklimi ile ögrenci kontrol ideolojileri arasındaki ilişki [The relationship between school principal manegerial effectiveness and school climate with pupil control ideologies in elementary schools] (Yayımlanmamış yüksek lisans tezi). Eskişehir Osmangazi Üniversitesi Eğitim Bilimleri Enstitüsü, Eskişehir.

Yılmaz, K. (2002), İlköğretim okulu müdürlerinin liderlik davranışlarlyla öğretmenlerin ögrenci kontrol yaklaşımları ve ögrencilerin okul yaşamının niteliğine ilişkin algıları arasindaki ilişkiler $[A$ Study of leadership behaviors of primary school's administrators, the pupil control ideology as prceived by teachers and the quality of school life as perceived by students] (Yayımlanmamış yüksek lisans tezi). Eskişehir Osmangazi Üniversitesi Eğitim Bilimleri Enstitüsü, Eskişehir. 
Yılmaz, K. (2007) İlköğretim okulu öğretmenlerinin okul yöneticilerinin liderlik davranışları ve öğrenci kontrol ideolojilerine ilişkin görüşleri [The opinions of primary school teachers concerning administrators' leardership behaviors and pupil control ideologies]. TED Ĕgitim ve Bilim Dergisi, 32(146), 12-23.

Y1lmaz, K. (2009). Primary school teachers' views about pupil control ideologies and classroom management styles. Cypriot Journal of Educational Sciences, 4, 157-167.

Yılmaz, K. (2011). Öğretmen adaylarının demokratik değerler ile öğrenci kontrol ideolojilerine ilişkin görüşleri arasındaki ilişki [The relationship between democratic values of prospective teachers and their views about pupil control ideologies]. Uludağ Üniversitesi Ĕgitim Fakültesi Dergisi, 24(2), 297-315. 